\title{
PERSEPSI ANGGOTA NON MUSLIM TERHADAP PEMASARAN ISLAM DI KSPPS KI AGENG PANDANARAN SEMARANG
}

\author{
Siti Rofik Atus Sa'diyah1, Wahibur Rokhman² \\ ${ }^{12}$ Institut Agama Islam Negeri Kudus \\ $\triangle$ wahibur@iainkudus.ac.id ${ }^{2}$
}

Abstrak: Penelitian ini bertujuan untuk menganalisis persepsi anggota non muslim terhadap pemasaran Islam yang diterapkan Koperasi Simpan Pinjam dan pembiayaan Syariah (KSPPS) Ki Ageng Pandanaran Semarang. Penelitian ini merupakan penelitian lapangan dengan pendekatan kualitatif deskriptif. Sumber data penelitian ini wawancara dengan lima anggota non muslim yang menggunakan berbagai produk jasa dan nara sumber dari dua orang pengelola KSPPS. Hasil penelitian ini menunjukkan bahwa pemasaran Islam sangat mendorong minat masyarakat non muslim dalam bergabung menjadi anggota. Pemasaran Islam yang ditawarkan antara lain: kesuaian produk-produk yang ditawarkan dengan kebutuhan anggota, akad yang diterapkan secara terbuka dan adil, sikap jujur, transparan, serta memberikan pelayanan yang baik di KSPPS Ki Ageng Pandanaran Semarang. Penelitian ini memiliki kontribusi praktis bagi manajerial lembaga keuangan mikro syariah dalam memperluas pasar tidak hanya dari kalangan muslim tetapi juga non muslim.

Kata kunci: Pemasaran Islam, Anggota Non Muslim, Persepsi Anggota

\section{LATAR BELAKANG}

Pemasaran memiliki peran yang sangat penting bagi kelangsungan hidup suatu usaha. Keunggulan dalam memenangkan persaingan banyak dipengaruhi oleh strategi pemasaran yang digunakan oleh perusahaan. Kompetisi yang semakin ketat mendorong pemilik usaha untuk merupakan salah satu faktor penting yang saat ini dipertimbangkan sebagai bagian dari manajemen untuk meningkatkan daya saing usaha untuk memenangkan persaingan terutama usaha kecil.

Pemasaran Islam merupakan sebuah usaha yang mengarahkan proses penciptaan, penawaran, dan perubahan nilai atau value dari satu inisiator kepada stakeholders nya, yang dalam keseluruhan prosesnya sesuai dengan akad serta prinsip syariah dan muamalah dalam Islam (Alma dan Priansa, 2014). Ada berbagai penelitian yang terkait dengan minat nasabah (anggota), contoh Andespa (2017) menemukan berbagai faktor yang mempengaruhi minat nasabah dalam mengambil keputusan di bank syariah antaralain: faktor bauran pemasaran (strategi produk, penentuan harga, distribusi dan promosi), faktor budaya (budaya dan kelas sosial), faktor pribadi (kelompok acuan, keluarga, peran dan status atau kedudukan dari seseorang dalam masyarakat), dan faktor psikologi (terdiri dari persepsi seseorang, motivasi, pembelajaran, keyakinan dan sikap. Penelitian Mubarok dan Maldina (2017) menemukan bahwa praktik pemasaran islami memiliki peran penting dalam peningkatan penjualan pada Butik Calista. Wibowo dan Haryati (2020) menemukan peran budaya dan persepsi masyarakat non muslim terhadap pengambilan keputusan untuk menjadi nasabah dalam lembaga keuangan syariah di Bengkalis. 
Dari berbagai penelitian di atas, maka penelitian ini bertujuan untuk meneliti persepsi anggota non muslim terhadap pemasaran Islam digunakan oleh KSPPS Ki Ageng Pandanaran Semarang. Penelitian ini diharapkan memberi kontribusi terhadap pengembangan pengetahuan terkait dengan praktik pemasaran islam yang masih sangat terbatas, penelitian ini juga memberi kontribusi terhadap pemahaman stake holder lembaga mikro syariah untuk menarik nasabah tidak hanya yang beragama Islam tetapi juga pada non Muslim.

\section{TEORI DAN METODE}

\subsection{Pemasaran Islam}

Pemasaran merupakan suatu kegiatan manusia atau perusahaan untuk dalam memenuhi kebutuhan dan keinginannya melalui proses pertukaran, sehingga dapat memberikan kepuasan pada suatu individu atau kelompok. Hal ini disebabkan karena pemasaran merupakan salah satu kegiatan perusahaan yang secara langsung berhubungan dengan konsumen. Maka dalam menjalankan usahanya perusahaan menerapkan proses pemasaran berdasarkan pada beberapa konsep inti pemasaran meliputi: Kebutuhan, keinginan, dan permintaan, Produk, Nilai, biaya, dan kepuasan, Pertukaran, transaksi, dan hubungan dan Pasar (Al Arif, 2017).

Pemasaran dapat diartikan sebagai pengolahan pasar yang dapat menghasilkan transaksi atau pertukaran dengan tujuan untuk memberikan kepuasan terhadap kebutuhan dan keinginan konsumen. Pemasaran pada umumnya meliputi memberikan pelayanan pada pasar pengguna akhir dengan pesaing. Suatu proses pemasaran tidak akan berjalan tanpa adanya seorang pemasar atau pihak yang menawarkan suatu produk atau manfaatnya kepada pasar sasaran produknya. Jika suatu pihak lebih aktif mengusahakan dalam proses pertukaran dibandingkan dengan pihak lain, maka ditegaskan bahwa pihak pertama sebagai pemasar dan pihak kedua sebagai calon pembeli atau prospek.

Pemasaran Islam (Syariah marketing) merupakan disiplin bisnis strategis yang mengarahkan pada proses penciptaan, penawaran, dan perubahan nilai dari satu inisiator kepada stakeholder nya dan dalam semua prosesnya disesuaikan dengan prinsip-prinsip muamalah dan akadnya ( Sula dan Kertajaya, 2009). Pemasaran Islam merupakan rencana perusahaan untuk mencapai suatu tujuan dengan menerapkan suatu disiplin bisnis pada keseluruhan prosesnya, baik proses penciptaan, proses penawaran, dan proses perubahan nilai dari seorang produsen atau satu perusahaan maupun perorangan yang kegiatannya selalu dilandaskan pada prinsip syariah dan muamalah dalam Islam serta tidak bertentangan dengan akad, sehingga antara penjual dan pembeli dapat mencapai kesejahteraan baik material maupun spiritual. Adapun karakter pemasaran islami telah dicontohkan oleh Nabi sebagai berikut:

a) Ketuhanan atau Rabbaniyah, merupakan suatu keyakinan yang bulat pada diri seseorang bahwa semua tingkah laku yang dilakukan seseorang selalu berada dibawah pengawasan Allah dan akan dipertanggung jawabkan. Hal ini merupakan salah satu karakter pemasaran Islam, sehingga pemasar harus berperilaku sebaik mungkin, selalu bekata jujur baik dalam lisan maupun dalam tindakan, tidak berperilaku licik, tidak suka menipu, mencuri, dan 'memakan harta orang lain dengan jalan yang batil dan sebagainya. Hal tersebut sesuai dengan firman Allah QS. Al-Baqarah ayat 188 
b) Etis atau Akhlaqiyah, yaitu semua perilaku yang dilakukan masyarakat didasarkan pada norma etika yang berlaku untuk umum. Dalam pemasaran Islam, pemasar harus menjunjung tinggi akhlak dalam menjalankan kegiatan dan dalam pemasarannya tidak diperbolehkan untuk menghalkan berbagai cara untuk mengambil untung yang sebanyak-banyak nya.

c) Realistis atau Al-Waqiiyah, yaitu sesuai dengan realita (kenyataan), tidak mengada-ada apalagi menjerumus pada kebohongan. Maksudnya yaitu semua transaksi yang dilakukan oleh setiap perusahaan harus didasarkan pada realitanya, tidak membedabedakan pembeli melalui status, suku maupun warna kulitnya. Berdasarkan karakter ini semua tindakan yang dilakukan oleh perusahaan dilakukan dengan jujur.

d) Humanistis atau Al-Insaniyah, yaitu berperikemanusian atau saling menghormati antar sesama, karena syariah Islam diciptakan untuk mengangkat derajat manusia agar sifat kemanusiaan terhadap sesamanya dapat terjaga. Dengan adanya sifat ini manusia diharapkan untuk tidak membeda-bedakan antar warna kulit, ras, suku dan sebagainya. Sehingga keharmonisan antar sesama manusia dapat terjaga dengan baik tanpa adanya tumpang tindih antar golongan. Dalam perniagaan seorang marketer juga diharapkan memiliki sifat humanistis ini dalam artian memperlakukan manusia selayaknya manusia tanpa memandang kasta.

\subsection{Persepsi Anggota}

Persepsi merupakan suatu proses yang dilakukan oleh seseorang dalam mengorganisasikan dan menafsirkan stimulus yang dipengaruhi keinginan seseorang, pengetahuan seseorang, serta pengalaman yang relevan. (Paradikma, 2019) Nasabah (anggota) adalah seseorang yang terikat dengan lembaga keuangan baik bank maupun lembaga keuangan non bank, misalnya seperti koperasi, BMT, dan sebagainya. Dimana orang tersebut terkait dalam urusan menyimpan ataupun meminjam. Sedangkan menurut KBBI, nasabah (anggota) merupakan seseorang yang mempunyai hubungan dengan lembaga keuangan. (Syafrina dan Manik, 2018) Sedang pengertian dari non-muslim yaitu seseorang yang mempunyai keyakinan diluar agama Islam. Jadi dari pengertian diatas dapat disimpulkan bahwa persepsi nasabah (anggota) non muslim merupakan cara pandang seseorang baik nasabah atau anggota yang memiliki perbedaan keyakinan terhadap suatu objek dengan cara yang berbeda sesuai dengan pengetahuan, pengalama, dan keinginan yang dapat memberikan reaksi pada panca indera yang digunakan.

Pada umumnya persepsi seseorang terjadi karena 2 faktor utama: pertama, Faktor internal atau faktor yang berasal dari dalam, meliputi:

1. Sikap merupakan salah satu aspek yang memiliki peranan penting dalam mempengaruhi persepsi. Hal ini dapat dilihat melalui sikap customer servis dalam memberikan pelayanan baik dalam ucapan atau tindakan, maka hal itu sangat berpengaruh terhadap anggota atau masyarakat dalam memberikan suatu tanggapan positif.

2. Motivasi yaitu suatu dorongan yang berasal dari sikap yang diberikan oleh perusahaan terhadap konsumennya.

3. Harapan yaitu angan-angan dari seorang nasabah terhadap suatu perusahaan dalam memberikan produk yang berkualitas dan sesuai dengan apa yang mereka inginkan. 
4. Minat yaitu penilaian yang diberikan oleh konsumen pada produk perusahaan, sehingga penilaian dari konsumen dapat dijadikan sebagai pandangan masyarakat dalam memilih suatu produk.

5. Suasana hati yaitu perasaan dari seseorang yang dapat berpengaruh bagi orang disekitarnya dalam mengungkapkan suatu persepsi.

6. Pengalaman yaitu suatu kejadian yang pernah dialam pada masa lalu, sehingga dari dari kejadian tersebut dapat ditarik kesimpulan yang sama dengan apa yang pernah didengar maupun dilihat oleh sesrorang. (Roy dkk, 2020)

7. Perhatian yaitu salah satu faktor yang berasal dari dalam diri seseorang, sehingga seseorang akan membutuhkan energi yang dikeluarkan untuk memfokuskan bentuk fasilitas yang terdapat pada objek (Yuniarti, 2019).

Sedangkan faktor eksternal atau faktor yang berasal dari luar, meliputi:

1. Latar belakang, Latar belakang keluarga, merupakan salah satu yang berpengaruh pada persepsi seseorang. Pada umumnya latar belakang dapat dilihat pendidikan, jenis aktivitas ekonomi, pendapatan keluarga, serta posisi seseorang dalam masyarakat tersebut (Deriyanto dan Qorib, 2018)

2. Informasi merupakan suatu pesan yang dapat disampaikan oleh seseorang melalui proses komunikasi. Maka tanpa adanya media sosialisasi atau komunikasi seorang konsumen tidak akan pernah mengetahui dan mengenal produk-produk yang ditawarkan oleh suatu perusahaan.

3. Intensitas Intensitas, merupakan suatu rangsangan yang sering diberikan oleh objek dengan tujuan untuk mendapatkan banyak perhatian dari masyarakat, karena pada dasarnya pemasaran yang intensif akan mendapatkan banyak tanggapan daripada pemasaran yang kurang intensif.

4. Ukuran objek Ukuran objek, merupakan salah satu faktor yang mempengaruhi persepsi seseorang. Hal tersebut dapat kita lihat melalui objek yang semakin besar pada umumnya akan lebih menarik perhatian.

5. Pengulangan gerak

Pengulangan gerakan, dpat dapat berpengaruh pada persepsi seseorang karena benda yang bergerak sering dianggap lebih menarik perhatian masyarakat daripada benda yang diam. (Roy, dkk, 2020)

\subsection{Metode Penelitian}

Penelitian ini merupakan penelitian deskriptif dengan menggunakan pendekatan kualitatif. Penelitian ini bermaksud untuk memahami fenomena tentang apa yang dialami oleh subjek penelitian salah satunya seperti kesenjangan sosial yang dapat berpengaruh negatif terhadap persepsi suatu masyarakat, Sehingga penelitian ini bisa dijadikan sebagai alternatif suatu gambaran bagi masyarakat non muslim bahwa lembaga yang berbasis syariah tidak hanya ditujukan untuk umat muslim saja, akan tetapi juga ditujukan bagi seluruh umat (non muslim). Sumber data yang digunakan dalam penelitian ini yaitu sumber data primer dan sumber data sekunder. Data primer diperoleh melalui wawancara secara langsung dan pengamatan lapangan dengan beberapa informan, sedangkan data sekunder dalam penelitian ini diperoleh melalui jurnal-jurnal, artikel, dan berbagai dokumentasi dari subjek penelitian. (Idrus, 2009) Adapun teknik pengumpulan data dalam penelitian ini dilakukan melalui observasi, wawancara, dan dokumentasi (Nugrahaini, 2014) Sedangkan teknik analisis data yang digunakan dalam penelitian ini adalah analisis kualitatif yang 
mencakup reduksi data, penyajian data, dan penarikan kesimpulan (Sugiyono, 2013).

\section{HASIL DAN PEMBAHASAN \\ 3.1 Penerapan Konsep Pemasaran}

Konsep pemasaran mempunyai peranan penting dalam mengembangkan dan memperluas jaringan pemasaran KSPPS Ki Ageng Pandanaran Semarang. Diantaranya dengan memenuhi kebutuhan dan keinginan serta menarik minat anggota muslim maupun non muslim dan menjaga loyalitas anggota yang sudah ada. (Maryono dan Sri Lestari personal communication, Oktober 19, 2020) Anggota merupakan aset terpenting dalam suatu lembaga keuangan syariah (KSPPS) yang mana anggota menjadi pelaku aktif dalam menjalankan KSPPS. Karena pada dasarnya keberhasilan suatu koperasi dapat dilihat dari jumlah anggota yang bergabung, bukan dari jumlah koperasi yang didirikan. Untuk meningkatkan jumlah anggota, KSPPS Ki Ageng Pandanaran Semarang telah menerapkan konsep pemasaran yang dilandaskan pada sifat-sifat Nabi yang sudah berhasil dalam menjalankan bisnis (Maryono, personal communication, Oktober 19, 2020) diantanya:

Pertama, Shidiq atau berperilaku baik dan simpatik dalam penerapan KSPPS Ki Ageng Pandanaran Semarang telah menerapkan konsep pemasaran Islam sesuai dengan ajaran Nabi yaitu melakukan pemasaran secara terbuka (tidak ada yang ditutup-tutupi), tidak melakukan penipuan/berbohong pada anggota, serta dalam menjalankan operasional seluruh staff KSPPS Ki Ageng Pandanaran Semarang berusaha untuk tidak mengucapkan sesuatu yang bertentangan dengan perbuatannya.

Kedua, Amanah atau jujur dan terpercaya, KSPPS Ki Ageng Pandanaran Semarang menerapkan sikap ini dengan cara menepati janji, jujur, memberikan pelayanan yang optimal, dan terbuka. Ketiga, tabligh atau memberikan pelayanan dan penyampaian yang dilandaskan pada kebenaran, kejujuran, serta tutur kata yang tepat. Keempat, Fathanah atau cerdas dan bijaksana, dalam penerapan KSPPS Ki Ageng Pandanaran Semarang telah berusaha untuk meningkatkan kualitas sumber daya manusia dengan cara mengikuti berbagai pelatihan dan menjadi anggota PBMT Indonesia, dengan tujuan untuk memperluas wawasan mengenai manajemen KSPPS. Sehingga dengan adanya sifat ini seorang pemasar atau perusahaan dapat menumbuhkan kemampuan dan kreativitas untuk menciptakan berbagai inovasi baru dan bermanfaat.

\subsection{Penerapan Strategi Pemasaran}

Setiap perusahaan memiliki tujuan untuk mengembangkan usahanya dan tujuan tersebut dapat dicapai melalui usaha meningkatkan kualitas perusahaan salah satunya dengan mempertahankan dan meningkatkan produknya melalui usaha mempertahankan anggota yg sudah ada, mencari anggota baru, serta berusaha menguasai pasar tersebut. Strategi pemasaran merupakan target pasar yang sudah ditentukan. (Nurul M, 2017:78) Sehingga KSPPS Ki Ageng Pandanaran Semarang menggunakan beberapa unsur strategi pemasaran yang digunakan untuk memenuhi kebutuhan dan menarik minat masyarakat sekitar untuk bergabung menjadi anggota. Adapun unsur strategi pemasaran yang diterapkan meliputi:

a) Strategi segmentasi atau pengelompokan pasar sasaran berdasarkan pada keinginan, kebutuhan, dan kesamaan respon terhadap suatu produk. 
Segmentasi yang diterapkan KSPPS Ki Ageng Pandanaran Semarang diterapkan berdasarkan wilayah dan kebutuhan masyarakat, hal ini dilakukan dengan tujuan untuk menentukan kegiatan pemasaran di segmen mana yang perlu diutamakan dan ditentukan berdasarkan pada kebutuhan masyarakat. (Sri L, personal communication, Oktober 19, 2020)

b) Strategi targeting dalam perusahaan bertujuan untuk memilih pasar sasaran yang memiliki potensi tinggi dan dapat menguntungkan bagi perusahaan. Sehingga pasar tersebut dapat dijadikan sasaran oleh perusahaan dalam menawarkan suatu produk-produk perusahaan. KSPPS Ki Ageng Pandanaran Semarang memilih target dengan menerapkan pola Single segmen concentration atau segmen tunggal yang potensial berdasarkan wilayah seperti Mugassari, Petek, Gayam, dan lain-lain karena tingginya tingkat anggota atau konsumen dari produk yang ditawarkan oleh KSPPS Ki Ageng Pandanaran Semarang. (Sri Lestari, personal communication, Oktober 19, 2020)

c) Strategi positioning adalah suatu cara yang dilakukan perusahaan dalam menempatkan suatu produk dibenak konsumen, menanamkan citra baik, persepsi, bahkan imajinasi atas produk-produk yang ditawarkan kepada konsumen melalui komunikasi. (Ali Mujahidin, 2019:288) KSPPS Ki Ageng Pandanaran Semarang telah menempatkan dirinya sebagai perusahaan yang menyediakan produk jasa yang aman, terpercaya, dan amanah. Sehingga hal tersebut menjadi keunggulan tersendiri bagi perusahaan dalam hal memenangkan persaingan pasar. (Sri Lestari, personal communication, Oktober 19, 2020)

Koperasi syariah merupakan salah satu lembaga keuangan mikro yang kegiatannya melakukan penghimpunan dana dari anggota dan disalurkan pada anggota dengan tujuan untuk mensejahterakan taraf hidup anggota maupun masyarakat sekitar yang berlandaskan pada syariah Islam. (Latifah dan Azlina, 2020) Oleh karena itu dalam kegiatan pemasarannya KSPPS Ki Ageng Pandanaran Semarang selalu dilandaskan pada semangat beribadah kepada Tuhan yang Maha Esa dan berusaha semaksimal mungkin dalam mewujudkan kesejahteraan bagi anggota dan masyarakat sekitar.

Strategi pemasaran Islam yang diterapkan KSPPS Ki Ageng Pandanaran Semarang dalam proses penciptaan dan penamawaran akan dianalisis berdasarkan dengan empat karakteristik pemasaran islam yang terdiri dari karakter ketuhanan, etika, realistis, dan kemanusiaan.

Pertama, ketuhanan atau sifat yang tertanam pada diri seseorang bahwa setiap kegiatan yang dilakukan selalu diawasi oleh Allah, dalam hal ini pemasaran yang dilakukan oleh KSPPS Ki Ageng Pandanaran Semarang sudah sesuai dengan apa yang anggota harapkan. Misalnya seperti dalam pemasaran KSPPS Ki Ageng Pandanaran Semarang selalu transparan atau terbuka, selalu berkata jujur dalam lisan maupun tindakan, dan selalu berperilaku baik. (Sri Lestari dan Anggota Non Muslim, personal communication, Oktober 19-20, 2020)

Kedua, etika dalam pemasaran Islam memiliki peranan penting, karena didalam etika terdapat nilai-nilai moral tanpa membeda-bedakan status sosial dan agama. (Ratna Purnama Sari, dkk, 2018:138) Dalam hal ini pemasaran yang dilakukan oleh KSPPS Ki Ageng Pandanaran Semarang sudah sesuai dengan pemasaran Islam yang memiliki karakter etika (akhlaqiyah) atau senantiasa selalu berperilaku sopan, ramah, santun, serta lembut dalam bertutur kata. 
Sehingga dapat memberikan kepuasan anggota serta menarik minat konsumen dalam memutuskan menjadi anggota. (Sri Lestari dan anggota Non Muslim, personal communication, Oktober 19-20, 2020)

Ketiga, realistis atau sesuai dengan realita. Dalam hal ini pemasaran yang dilakukan oleh KSPPS Ki Ageng Pandanaran Semarang dalam menerapkan pemasarannya memiliki karakter realistis atau dalam melakukan pemasaran KSPPS Ki Ageng Pandanaran Semarang selalu jujur dalam ucapan maupun tidakan, serta sesuai dengan kenyataan dan tidak ada yang ditutup-tutupi (transparan) baik dari kelebihan maupun kekurangan dari produk yang ditawarkan. (Sri Lestari dan Anggota Non Muslim, personal communication, Oktober 19-20, 2020)

Keempat, berperikemanusiaan dalam artian Islam bersifat universal atau menyeluruh. Penerapan dalam hal ini KSPPS Ki Ageng Pandanaran Semarang selalu memberikan pelayanan terbaik bagi seluruh anggota tanpa membedakan status anggota, agama, suku, ras maupun kedudukannya. (Sri Lestari dan Anggota Non Muslim, personal communication, Oktober 19-20, 2020).

\subsection{Persepsi Anggota Non Muslim terhadap Strategi Pemasaran Islam KSPPS Ki Ageng Pandanaran Semarang}

Persepsi nasabah (anggota) non muslim merupakan cara pandang seorang nasabah (anggota) yang memiliki perbedaan keyakinan terhadap suatu objek dengan cara yang berbeda sesuai panca indera yang digunakan. Pada umumnya persepsi nasabah (anggota) KSPPS Ki Ageng Pandanaran terjadi karena 2 faktor utama yaitu: pertama, faktor internal yang terdiri dari, Sikap yang diberikan oleh KSPPS dalam memberikan dan melakukan seluruh kegiatan operasional, baik terhadap sesama staff maupun dengan anggotanya. (Doni, November 23, 2020) Motivasi atau dorongan yang diberikan oleh KSPPS kepada anggota lama maupun anggota baru, sehingga mereka dapat loyal dan tetap menggunakan produkproduk yang diberikan oleh KSPPS. Adapun dorongan yang diberikan oleh KSPPS terhadap anggota yaitu menyediakan berbagai produk yang sesuai dengan kebutuhan masyarakat, memberikan proses transaksi dan pelayanan dengan baik, sederhana, dan tidak dipersulit. Sehingga seluruh anggota dari KSPPS Ki Ageng Pandanaran Semarang dapat merasa nyaman dan senang dalam menggunakan produk yang disediakan. (I Lies Ismawati $\mathrm{H}$, personal communication, November 23, 2020).

Harapan atau angan-angan dari seorang nasabah (anggota) terhadap produk yang diberikan oleh KSPPS. Adapun salah satu harapan dari anggota non muslim yaitu perusahaan mau memberikan produk pembiayaan dengan mudah dan bagi hasil yang sesuai. Penerapan yang dilakukan KSPPS yaitu memberikan berbagai layanan dan produk yang sesuai dengan harapan anggota (masyarakat). Sehingga hal tersebut dapat memberikan dampak positif terhadap persepsi anggota KSPPS Ki Ageng Pandanaran Semarang. (Maria Jumiati, personal communication, November 23, 2020) Minat atau suatu penilaian yang diberikan oleh konsumen terhadap suatu perusahaan. Untuk menarik minat dari masyarakat non muslim KSPPS Ki Ageng Pandanaran Semarang memberikan kemudahan dalam memberikan pelayanan bagi semua anggotanya tanpa membeda-bedakan agama yang dianut oleh anggota. (Ani Fariyati, personal communication, November 23, 2020). 
Suasana hati seorang nasabah atau anggota dapat memberikan dampak positif maupun negatif terhadap perusahaan. Maka dari itu untuk menjaga suasana hati anggota KSPPS Ki Ageng Pandanaran Semarang menerapkan menjalin hubungan baik dengan anggota serta memahami karakter dari anggota tersebut. Sehingga dapat memberikan pelayanan yang sesuai dengan keinginan anggota. Hal ini merupakan salah satu cara untuk menjaga suasana hati dari anggota KSPPS Ki Ageng Pandanaran Semarang. Pengalaman merupakan salah satu faktor yang dapat mempengaruhi persepsi seseorang. Penerapan yang dilakukan KSPPS Ki Ageng Pandanaran Semarang yaitu berusaha semaksimal mungkin dalam memberikan suatu produk jasa yang berkualitas dan baik, sehingga masyarakat yang menjadi anggota pada KSPPS memiliki pengalaman yang positif selama menjadi anggota dan hal ini dapat memberikan daya tarik tersendiri bagi masyarakat lainnya (Sri Rejeki Suhartono, personal communication, November 23, 2020).

Perhatian merupakan pemusatan dari seluruh aktivitas seseorang yang ditujukan pada bentuk yang terdapat pada fasilitas objek. hal ini sesuai dengan persepsi dari berbagai masyarakat non muslim yang menyatakan bahwa mereka tertarik untuk bergabung pada KSPPS Ki Ageng Pandanaran Semarang karena proses pelayanan yang diberikan kepada anggota. Sedangkan sebagian dari anggota non muslim tertarik untuk bergabung menjadi anggota KSPPS Ki Ageng Pandanaran Semarang karena produk-produk yang disediakan sesuai dengan apa yang mereka butuhkan. Dari hal ini dapat diketahui bahwa dalam kehidupan seseorang terdapat banyak rangsangan, meskipun demikian seseorang tidak harus merespon semua rangsangan yang diterimanya. Oleh karena itu seseorang dapat memusatkan rangsangan tersebut atau perhatian pada hal-hal tertentu saja seperti fasilitas yang terdapat pada objek, baik produk yang diberikan atau pelayanannya.

Kedua, faktor eksternal yang terdiri dari: Latar belakang keluarga berpengaruh terhadap persepsi seseorang berdasarkan pada pendidikan, jenis aktivitas ekonomi, pendapatan keluarga, serta posisi seseorang dalam masyarakat tersebut. Sehingga masyarakat yang berpendidikan tinggi dapat memberikan respon pada suatu informasi secara rasional dan berfikir sejauh mana keuntungan yang akan diperoleh. Oleh karena itu KSPPS Ki Ageng Pandanaran Semarang menerapkan berbagai produk dengan bagi hasil sesuai dengan kesepakatan antara anggota dengan perusahaan. Sehingga hal ini dianggap sangat membantu bagi masyarakat dalam meningkatkan taraf hidup yang lebih sejahtera. Informasi atau pesan yang disampaikan melalui komunikasi sehingga konsumen mengetahui produk yang ditawarkan oleh perusahaan. Adapun penerapan yang dilakukan KSPPS Ki Ageng Pandanaran Semarang, memberikan informasi melaui sosialisasi dan presentasi secara langsung pada saat acara pengajian, melakukan komunikasi dengan masyarakat sekitar, serta menjelaskan tentang produk-produk yang ditawarkan oleh KSPPS.

Intenitas merupakan rangsangan yang diberikan oleh KSPPS Ki Ageng Pandanaran Semarang untuk menarik banyak perhatian yaitu menyediakan pinjaman bagi anggota yang sangat membutuhkan tanpa memberikan biaya tambahan dalam proses pengembaliannya. Ukuran objek merupakan faktor yang menarik perhatian hal ini juga dapat diterapkan melalui jarak lokasi, adapun jarak lokasi KSPPS Ki Ageng Pandanaran Semarang lebih relatif mudah dijangkau masyarakat. hal tersebut juga dapat menarik perhatian dan minat masyarakat 
tersendiri untuk memilih dan bergabung menjadi anggota KSPPS Ki Ageng Pandanaran Semarang. Jemput Bola, dalam hal ini penerapan yang dilakukan KSPPS Ki Ageng Pandanaran Semarang yaitu memberikan layanan jemput bola terhadap anggotanya, sehingga masyarakat banyak yang tertarik untuk bergabung menjadi anggota karena pelayanan tersebut dianggap lebih memudahkan masyarakat untuk menyimpan dan pengambilan tanpa harus antri dan datang ke kantor langsung.

\section{PENUTUP}

Penelitian ini bertujuan untuk mengetahui persepsi anggota Non Muslim terhadap Pemasaran Islam di KSPPS Ki Ageng Pandanaran Semarang. Ada beberapa temuan dalam penelitian ini, antara lain: Pertama, penerapan Konsep Pemasaran Islam dalam meningkatkan anggota muslim maupun non muslim pada KSPPS Ki Ageng Pandanaran Semarang dilakukan dengan menggunakan konsep pemasaran berdasarkan pada sifat-sifat Nabi yang sudah berhasil dalam menjalankan bisnis. Hal ini dilakukan dengan bertujuan untuk memberikan daya tarik terhadap minat masyarakat muslim maupun non muslim untuk bergabung pada KSPPS Ki Ageng Pandanaran Semarang. Penerapan konsep pemasaran ini cukup memberikan hasil yang baik bagi KSPPS dalam menarik minat masyarakat.

Kedua, ada beberapa cara yang dilakukan KSPPS Ki Ageng Pandanaran Semarang dalam menerapkan pemasaran Islam dalam upaya untuk meningkatkan minat anggota muslim yaitu dengan melakukan pengelompokan berdasarkan segmen pasar, memilih pasar sasaran, serta menentukan suatu produk yang berkualitas (mampu memenuhi kebutuhan, keinginan, serta memberikan kepuasan terhadap konsumen). Selain itu, ada beberapa faktor-faktor pendukung lainnya dalam menjalankan strategi pemasaran Islam yaitu KSPPS Ki Ageng Pandanaran Semarang menerapkan strategi pemasaran Islam berdasarkan teori dan konsep Islam yang terdiri dari karakteristik Islami, penerapan etika bisnis Islam, serta mencontoh sifat-sifat Nabi dalam menjalankan bisnisnya (Shidiq, Amanah, Tabligh, Fathanah).

Ketiga, ada dua faktor utama yang dipertimbangkan dan diterapkan oleh KSPPS dalam menjalankan operasionalnya sehingga dapat mempengaruhi terbentuknya suatu persepsi positif oleh seluruh anggota khususnya pada anggota non muslim, meliputi: a) faktor internal yang penerapannya dilakukan dalam sikap, motivasi, harapan, minat, suasana hati, pengalaman, dan perhatian. b) faktor eksternal yang penerapannya dilakukan berdasarkan latar belakang anggota, informasi, intensitas, ukuran objek, dan pengulangan gerak.

Penelitian ini memberikan kontribusi praktis dan teoritis, kontribusi praktis dari penelitian ini diharapkan dapat memperluas wawasan berfikir pengelola lembaga keuangan mikro syariah dalam memperluas cakupan pemasaran tidak hanya muslim tetapi juga non muslim. Sedangkan kontribusi teoritis dari penelitian ini antara lain: penelitian ini diharapkan dapat memberikan sumbangan pengetahuan ilmu manajemen pemasaran islam serta memberikan kontribusi positif untuk para akademisi khususnya bagi peneliti untuk dapat mengetahui lebih mendalam tentang pemahaman strategi pemasaran Islam dan dapat memperluas kepustakaan sehingga dapat dijadikan referensi penelitian yang akan datang setelah diadakannya penelitian ini.

Meskipun penelitian ini memiliki kontribusi positif baik praktis maupun teoritis, tetapi penelitian ini memiliki berbagai keterbatasan, antara lain: 
penelitian hanya dilakukan di KSPPS Ki Ageng Pandanaran Semarang sehingga hasil penelitian ini tidak bisa digeneralisasi di lemabga keuangan mikro secara lebih luas. Kedua, penelitian ini dilakukan dalam waktu singkat, sehingga banyak fakta dan data lapangan mungkin tidak bisa tertangkap secara utuh, sehingga penelitian yang akan datang bisa melakukan penelitian jangka panjang sehingga dapat hasil penelitian yang lebih baik dan lebih komprehenship. 


\section{REFERENCE}

Abdi, M.K dan Febriyanti, N (2020). Penyusunan Strategi Pemasaran Islam dalam Berwirausaha di Sektor Ekonomi Kreatif Pada Masa Pandemi Covid-19. elQist: Journal of Islamic Economics and Business, 10(2), 60-70

Al Arif, M. N (2012). Dasar-Dasar Pemasaran Bank Syariah. Alfabeta, Bandung.

Alma, B dan Priansa (2014). Manajemen Bisnis Syariah. Alfabeta, Bandung.

Andespa, R. (2017). Faktor-Faktor yang Mempengaruhi Minat Nasabah dalam Menabung di Bank Syariah, Jurnal Lembaga Keuangan dan Perbankan, 2, no.1: 56.

Atmoko, T. P. H (2018). Strategi Pemasaran untuk Meningkatkan Volume Penjualan di Cavinton Hotel Yogyakarta. Jurnal of Indonesian Tourism, Hospitality and Recreation, 1(2), 83 - 96.

Hasil wawancara dengan Bapak Maryono (Manajer Utama) pada tanggal 19 Oktober 2020 pukul 08.00 WIB.

Hasil wawancara dengan Ibu Sri Lestari (Staff Pemasaran) pada tanggal 19 Oktober 2020 pukul 09.30 WIB.

Hasil wawancara dengan Ibu Sri Lestari (Staff Pemasaran) dan anggota non muslim pada tanggal 19-20 Oktober 2020 pukul 09.30 WIB-Selesai.

Hasil wawancara dengan Ibu Ani Fariyati (Anggota Non Muslim) pada tanggal 23 November 2020 pukul 08.30 WIB.

Hasil wawancara dengan Ibu I Lies Ismawati H (Anggota Non Muslim) pada tanggal 23 November 2020 pukul 09.00 WIB.

Hasil wawancara dengan Bapak Doni (Anggota Non Muslim) pada tanggal 23 November 2020 pukul 09.30 WIB.

Hasil wawancara dengan Ibu Maria Jumiati (Anggota Non Muslim) pada tanggal 23 November 2020 pukul 10.00 WIB.

Hasil wawancara dengan Ibu Sri Rejeki Suhartono (Anggota Non Muslim) pada tanmggal 23 November 2020 pukul 10.30 WIB.

Hendra, T (2016). Pembangunan Ekonomi Islam dengan Pengembangan Koperasi Syari'ah. Jurnal Kajian Ekonomi Islam 1, no. $1: 114$.

Kotler, P., \& Keller, K. L. (2016). Marketing Management. Global Edition (1st ed.). Boston: Pearson Education Limited.

Krake, F. B. G. J. M. (2005). Successful brand management in SMEs: a new theory and practical hints. Journal of Product \& Brand Management, 14(4), 228-238.

Latifah, E dan Devi A. (2020). Strategi Sharia' Marketing Pick Up Service Koperasi Syariah TKI Artha Mulya Lamongan. Jurnal Pamator 13, no. 1: 156.

Leli, M (2019). Strategi Pemasaran dalam Perspektif Islam." Jurnal At-Tasyri'iy, 2, no. $1: 34-36$.

Idrus. M. (2009). Metode Penelitian Ilmu Sosial. PT Gelora Aksara Pratama, Yogyakarta.

Muali, C dan Khoirun, N. ( 2019). Pemasaran Syariah Berbantuan Media Sosial: Kontestasi Strategis Peningkatan Daya Jual. Jurnal Ekonomi Syariah 05, no. 02: 174.

Mubarok, N dan Eriza, Y, M (2017). Strategi Pemasaran Islami dalam Meningkatkan Penjualan pada Butik Calista. I-Economic 3, no. 1

Mujahidin, A dan Ifa, K (2019). Analisis Segmentasi, Targeting, Positioning (STP) pada Zakiyya House Bojonegoro, Prosiding Seminar Nasional Unimus 2: 288. 
Nugrahaini, F (2014). Metode Penelitian Kualitatif: dalam penelitian pendidikan bahasa. Surakarta: Cakra Books.

Paradikma, G (2019). Persepsi Mahasiswa KKI IAIN Samarinda terhadap Implementasi Islam Moderat. Tarbiyah Wa Ta'lim Jurnal Penelitian Pendidikan\&Pembelajaran 6, no. 1: 15.

Roy, S, E., Syaiful M, dan Pratiwi, I, E. (2020) . Persepsi Masyarakat terhadap Bank Syariah (Studi Kasus : Masyarakat Distrik Abepura)," El Mudhorib : Jurnal Kajian Ekonomi dan Perbankan Syariah 1, no. 1: 50.

Sahla, H. (2019). Konsep Pemasaran Dalam Perspektif Ekonomi Islam, Jurnal Pionir LPPM Universitas Asahan. 5(2), 57 - 61

Sugiyono, (2013). Metode Penelitian Bisnis. Alfabeta, Bandung.

Sula, M. S., dan Kartajaya, H (2006) Syariah Marketing. Mizan Pustaka.

Syafrina, N dan Sudarmin Manik. S. (2018). Faktor-Faktor yang Mempengaruhi Masyarakat Non Muslim Menabung di PT. Bank Syariah Mandiri, JEBI Jurnal Ekonomi dan Bisnis Islam) 3, no. 1: 64.

Vinna. S. Y. ( 2019)Perilaku Konsumen. Bandung: Pustaka Setia, 2015. (dikutip dalam Skripsi Anggun Triana Sari, "Pandangan Nasabah Non Muslim terhadap Prinsip Bagi Hasil Bank Syariah", : 11-12.

Wibowo, A. dan Hariyati, N (2020). Pengaruh Budaya dan Persepsi Masyarakat Non Muslim terhadap Keputusan menjadi Nasabah Bank Syariah Mandiri Kantor Cabang Pembantu Bengkalis," JPS (Jurnal Perbankan Syariah) 1, no.1: 41. 